\title{
Evaluation of Different Enriched Composts under Protected Organic Farming in Capsicum-pea based Cropping System
}

Rameshwar Kumar, Sanjay Chadha, R.G. Upadhyay, G.D. Sharma, Sangeeta Kanwar

10.18805/LR-4300

\begin{abstract}
Background: For the successful adoption of organic farming especially under protected cultivation conditions there is a dire need to enrich and fortify the different composts for meeting out the requirements of crops. Experiments were conducted at Model Organic Farm, Department of Organic Agriculture and Natural Farming, CSKHPKV, Palampur and at farmers field in Akrot, Una and Rajol Kangra of HP with an objective to evaluate different enriched composts under protected organic farming conditions.

Methods: The experiments were conducted with 9 treatments viz. Matka khad (M) + Rock phosphate (RP), Matka khad + Gypsum (G), Matka khad + Patent kali (PK), Matka khad + Lime (L), Matka khad + control, Matka khad + Combination of RP,G,PK,L + Tricoderma + Rhi/Azoto + PSB, Panchgavya + Combination of RP,G,PK,L + Tricoderma + Rhi/Azoto + PSB, Jeevamrit + Combination of RP,G,PK,L + Tricoderma + Rhi/Azoto + PSB and Vermicompost. These treatments were selected after preparation of enriched and fortified FYM and its evaluation by microbial and nutrient analysis. Pea crop variety $\mathrm{Pb}-89$ and Capsicum crop variety California wonder were selected for the experiments under polyhouse at research farm and at farmer's field.

Result: Results showed that inoculation of biomass with matka khad along with additives i.e. rock phosphate, gypsum, patent kali and lime @ of $1 \%$ and fortification with Tricoderma, suitable biofertilizer (Rhizobium/Azotobacter) along with PSB increased the yield of Pea crop more than $40 \%$ at organic farm and farmers fields, whereas in case of capsicum the increase in yield was to the tune of $14 \%$ at model organic farm and more than $40 \%$ at two different sites of farmers field.
\end{abstract}

Key words: Bio-fertilizers, Enriched, FYM, Liquid manure, Organic, Permitted additives.

\section{INTRODUCTION}

Agricultural soil has been adversely affected by chemical fertilizers, pesticides and heavy machinery and it has been observed that most of the soils are not responding towards productivity. On the other hand growing awareness of health and environmental issues in agriculture has demanded production of organic food which is emerging as an attractive source of rural income generation. Various organic manures like farm yard manure, vermicompost, green manure etc., that are added to the soil from time to time further add to the store of organic matter (Palaniappan and Annadurai, 1999). But the main problem usually farmers faced is that all organic manures are low in nutrient status which is insufficient to meet the basic requirement of crop so the need for the fortification or enrichment of compost with different natural substrates and microbes arises which will improve the quality of the compost in terms of nutrient status and microbial population. Nyamangara et al. (2003) reported that the organic waste composted manure application even enhanced the use efficiency of mineral nitrogen fertilizer by crops when the two were applied in combination. Under such circumstances, enrichment of organic manures and composts with permitted additives like rock phosphate, patent kali, bone manure, gypsum, lime, oil seed cake/cotton cake, sheep droppings and neem cake is a feasible option for nutrient supplementation in organic food production. Composting is one of the biological processes for recycling of organic waste and can be handled, stored and applied to land without any environmental impact (Eghball et al., 2004). Considering the above mentioned challenges the green
Department of Organic Agriculture and Natural Farming, College of Agriculture, CSK Himachal Pradesh Krishi Vishvavidyalaya, Palampur-176 062, Himachal Pradesh, India.

Corresponding Author: R.G. Upadhyay,, Department of Organic Agriculture and Natural Farming, College of Agriculture, CSK Himachal Pradesh Krishi Vishvavidyalaya, Palampur-176 062, Himachal Pradesh, India. Email: drrgupadhyay11@gmail.com

How to cite this article: Kumar, R., Chadha, S., Upadhyay, R.G., Sharma, G.D. and Kanwar, S. (2021). Evaluation of Different Enriched Composts under Protected Organic Farming in Capsicumpea based Cropping System. Legume Research. 44(8): 929-935. DOI: $10.18805 /$ LR-4300.

Submitted: 11-12-2019 Accepted: 23-10-2020 Online: 29-12-2020

biomass to be used for composting was treated with different liquid preparations viz; Matka khad, Panchgavya, Jeevamrit along with water considered as control with the objective of decreasing the period of its preparation and it was enriched with the different additives and microbes to form the enriched fortified compost. The objective of the present study was to evaluate the effect of fortified enriched compost under protected organic farming at Research farm and at farmers' field.

\section{MATERIALS AND METHODS}

The experiment was conducted at Research Farm of Department of Organic Agriculture and Natural Farming, Chaudhary Sarwan Kumar Himachal Pradesh Krishi Vishvavidyalaya, Palampur at an altitude of 1290.8 metre 
a.m.s.I with latitude $32^{\circ} 6^{\prime} \mathrm{N}$ and longitude $76^{\circ} 3^{\prime} \mathrm{E}$ and at two different farmers' sites at Akrot in Una at an altitude of 369 metre a.m.s.I with latitude $31^{\circ} 4^{\prime} \mathrm{N}$ and longitude $76^{\circ} 3^{\prime}$ $E$ and Rajol in Kangra at an altitude of 733 metre a.m.s.l with latitude $32^{\circ} 1^{\prime} \mathrm{N}$ and longitude $76^{\circ} 3^{\prime} \mathrm{E}$. The Research farm area represents the mid-hill wet temperate zone of Himachal Pradesh. Different organic inputs like Matka khad, Panchgavya, Jeevamrit etc were used for preparation of enriched compost (Table 1). After the preparation of enriched compost and its evaluation, shortlisted treatments were tested under protected conditions at Research farm and at farmers' field. Capsicum crop variety California wonder was transplanted on $20^{\text {th }}$ May with spacing of $50 \times 30 \mathrm{~cm}$ and first picking was taken on $2^{\text {nd }}$ July which continued up to $20^{\text {th }}$ August. Pea crop variety PB-89 was sown with spacing of $50 \times 5 \mathrm{~cm}$ on $12^{\text {th }}$ November and its first pick was taken on $4^{\text {th }}$ April which continued up to $25^{\text {th }}$ May.

\section{Preparation of enriched compost}

\section{Collection of green biomass and its inoculation with liquid manure}

Two to three days old green biomass was collected and placed in the form of heaps on $1 \mathrm{~m}^{3}$ area. Three inoculants namely matka khad, panchgavya, jeevamrit and water (control) were sprinkled over biomass layer by layer at the rate of 2 It. liquid manure per quintal biomass. This treated biomass was kept for 15 days for decomposition.

\section{Enrichment of main material (cow dung)}

After the partial decomposition of green material, it was enriched with different enrichments namely rock phosphate, gypsum, patent kali, combination of three (rock phosphate, gypsum, patent kali) along with control as per treatment. Other inputs such as bone manure, sheep droppings and oilseed cakes were also added as common in all the treatments. In order to upgrade nutrient content of the compost, nitrogen fixing bacteria, rock phosphate and phosphate solubilising microorganisms has been documented (Singh et al., 1992; Pazhanivelan et al., 2006). Five treatments per liquid manure were experimented.

\section{Fortification of enriched manures}

After the preparation of the enriched compost, this compost was further fortified with biofertilizers viz; Rhizobium,

Table 1: Different organic inputs and method of preparation.

\begin{tabular}{|c|c|c|}
\hline Name of the inputs & Ingredients & Method of preparation \\
\hline Matka khad & $\begin{array}{l}\text { Cow dung = } 5 \mathrm{~kg} \\
\text { Cow urine = } 5 \mathrm{lt} \text {. } \\
\text { Water = } 5 \text { It. } \\
\text { Jaggary = } 250 \mathrm{gm} \\
\text { Earthen Pitcher = } 1 \mathrm{no} . \\
\text { of } 20 \text { It. capacity }\end{array}$ & $\begin{array}{l}\text { Thoroughly mix } 5 \mathrm{~kg} \text { of cow dung, } 5 \mathrm{lt} \text {. cow urine, } 5 \mathrm{lt} \text {. water and } 250 \mathrm{gm} \text { of } \\
\text { jiggery and put in a pitcher of } 20 \text { It. capacity. The pitcher is filled up to } 3 / 4 \\
\text { level only, for effective fermentation. A lid is placed over the pitcher and } \\
\text { buried in the soil for } 7 \text { to } 10 \text { days with its neck outside the soil. }\end{array}$ \\
\hline Panchgavya & $\begin{array}{l}\text { Cow dung }=5 \mathrm{~kg} \\
\text { Cow urine }=3 \mathrm{lt} \\
\text { Cow dung slurry = } 4 \mathrm{~kg} \\
\text { Cow milk = } 2 \mathrm{lt} . \\
\text { Cow curd = } 2 \mathrm{~kg} \\
\text { Cow butter oil = } 1 \mathrm{~kg} \text { (ghee) }\end{array}$ & $\begin{array}{l}\text { It is a blend of } 5 \text { product obtained from cow mainly its dung, urine, milk, } \\
\text { ghee and curd. For making Panchgavya, thoroughly mix the required } \\
\text { quantities of the ingredients and allow to ferment for } 7 \text { days with twice stirring } \\
\text { per day. }\end{array}$ \\
\hline Jeevamrit & $\begin{array}{l}\text { Cow dung }=5 \mathrm{~kg} \\
\text { Cow urine }=5 \mathrm{lt} . \\
\text { Water }=50 \mathrm{lt} . \\
\text { Jaggary }=1 \mathrm{~kg} \\
\text { Pulse flour }=1 \mathrm{~kg} \\
\text { Fertile soil }=1 / 2 \mathrm{~kg}\end{array}$ & $\begin{array}{l}\text { Mix all the ingredients in a drum with the help of a wooden stick. Shake the } \\
\text { mixture 2-3 times per day regularly for 5-7 days for proper fermentation. }\end{array}$ \\
\hline Vermiwash & $\begin{array}{l}\text { Pitchers }=3 \\
\text { Earthworms (Eisenia } \\
\text { foetida) }=200-300 \text { (No) } \\
\text { Dung }=4-5 \mathrm{Kg} \\
\text { Dry Biomass = } 3-5 \mathrm{Kg} \\
\text { Pebbles = few } \\
\text { Rubber Pipe = 1m } \\
\text { Rope = 1-2 m }\end{array}$ & $\begin{array}{l}\text { Vermiwash was prepared by using three pitchers. In one of the pitcher a } \\
\text { hole was made at base and rubber pipe was fitted to it. In this pitcher few } \\
\text { pebbles were placed and } 2-3 \text { inches layer of sand was spread at the bottom } \\
\text { of the pitcher. Above this, a layer }(5 \mathrm{~cm}) \text { of dry biomass was also spread } \\
\text { which was further covered by a layer }(5 \mathrm{~cm}) \text { of cow dung. Then repeat these } \\
\text { two layers. As the material was filled up to } 2 / 3 \text { of pitcher, } 200-300 \text { adult } \\
\text { earthworms (Eisenia foetida) were added to it. A little biomass along with } \\
\text { water was added to it and the pitcher was hanged with the help of plastic } \\
\text { rope under a shady area. Another pitcher with a hole at the bottom and filled } \\
\text { with water was placed above the pitcher mentioned above so that water got } \\
\text { trickled drop wise in the pitcher having earthworms. Another empty pitcher } \\
\text { was placed below it to collect the vermiwash. }\end{array}$ \\
\hline
\end{tabular}




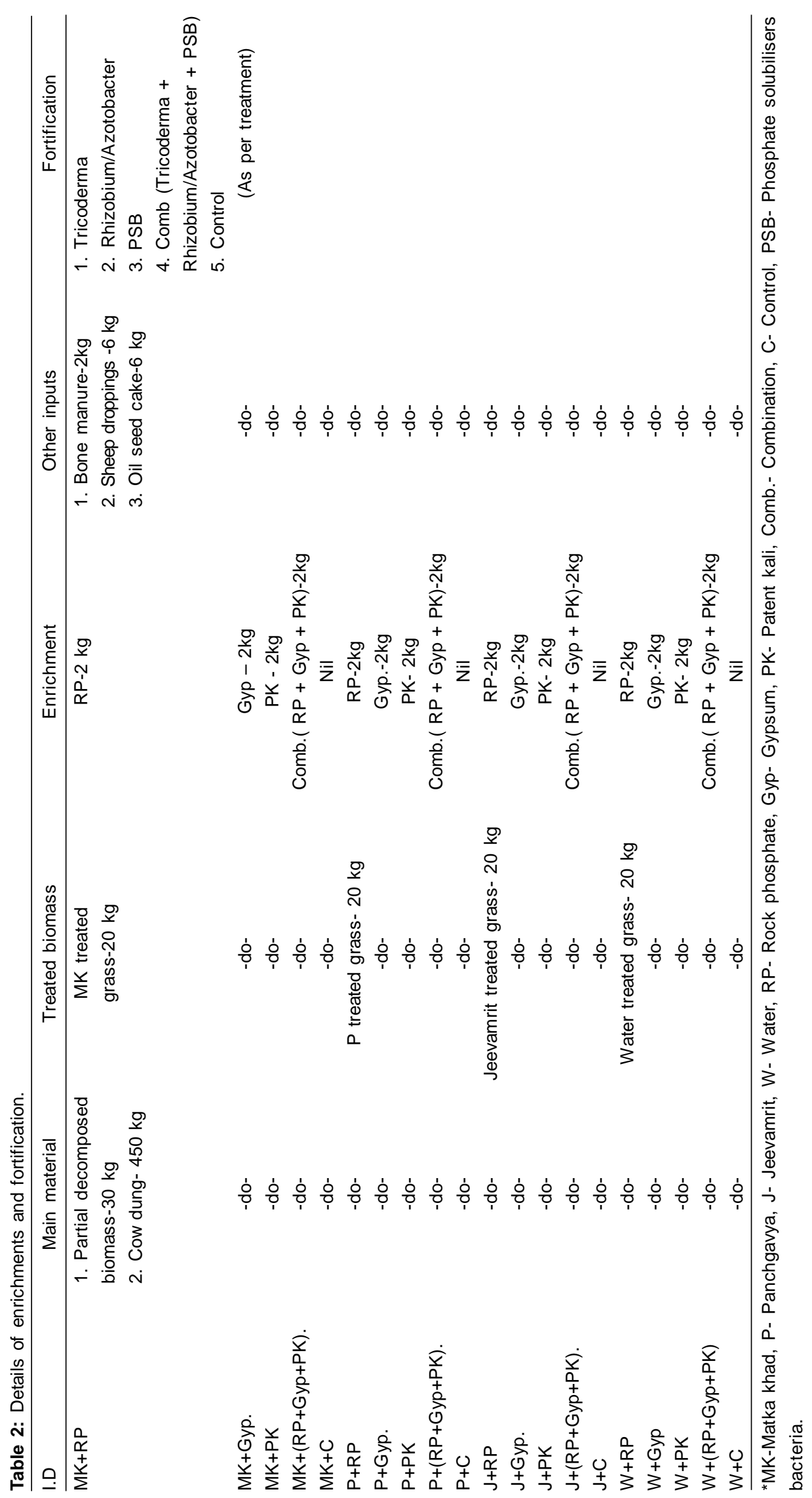


Tricoderma, phosphate solubilizers, combination of three [Rhizobium, Tricoderma, phosphate solubilizers (PSB)] and control in case of peas, whereas in case of capsicum Azotobacter was used. Fortification was done in pots containing $3 \mathrm{~kg}$ compost at the rate of $1 \mathrm{~kg}$ Tricoderma and $250 \mathrm{~g}$ Rhizobium/ Azotobacter and PSB per $25 \mathrm{~kg}$ compost. This fortified compost was used for conducting trials. The addition of compost or organic manure is an important way to improve the soil in degraded areas since nitrogen and other nutrients, as well as organic matter which improves soil structure, was added with the organic material (Caravaca et al. 2002; Muthukumar and Udaiyan, 2000, Nziguheba et al. 2000; Shrestha Vaidya et al. 2008). Polyhouse trial was conducted in $250 \mathrm{~m}^{2}$ area and best nine treatments were short listed on the basis of basic study and were further evaluated in the field conditions. Enriched and fortified compost was amended in the soil in separate plots according to treatments.

To manage different insect pest and diseases following spray schedule was followed.

Spray schedule: After 15 days of germination at 15 days interval.

- Milk (1 It.) + heeng $(50 \mathrm{~g})$ in 10 It. water spray.

- Neem oil (5 ml in 1 lt. water).

- Vermiwash (2 It.) + panchgavya (1 lt.) in 15 It. water.

- Milk (1 lt.) + heeng $(50 \mathrm{~g})$ in 10 lt. water spray.

In addition to this vermiwash drip was followed at weekly interval to meet out the nutrient requirements of the crops and initially at sowing or transplanting vermicompost was added in soil @ 10t/ha.

\section{RESULTS AND DISCUSSION}

Trial conducted at Research Farm

\section{Evaluation of different enriched composts in peas under polyhouse}

It was found that, different enriched composts improved plant population, most of the yield attributes and significantly produced higher yield as compared to vermicompost except MK + control which was significantly at par with vermicompost treatment. Yield from the treatments of $\mathrm{MK}+$ $(\mathrm{RP}+\mathrm{Gyp}+\mathrm{PK})+($ Tri+PSB+Rhi) and $\mathrm{MK}+$ Lime were the highest among all the treatments and was $39 \%$ higher than the vermicompost treatment followed by MK+ Gypsum 35\% higher (Table 3).

\section{Evaluation of different enriched composts in capsicum under polyhouse}

The different enriched composts significantly increased the height of plants as compared to vermicompost treatment except in MK + RP treatments where the plant height did not vary significantly. Tallest plants were recorded in $\mathrm{MK}+$ Gypsum treatment, significantly at par with the $M K+P K$ treatment. Different enriched composts significantly increased the number of fruits $/ \mathrm{m}^{2}$ in some of the treatments as compared to vermicompost treatment. Significantly higher number of fruits $/ \mathrm{m}^{2}$ were recorded in $\mathrm{MK}+$ Gypsum

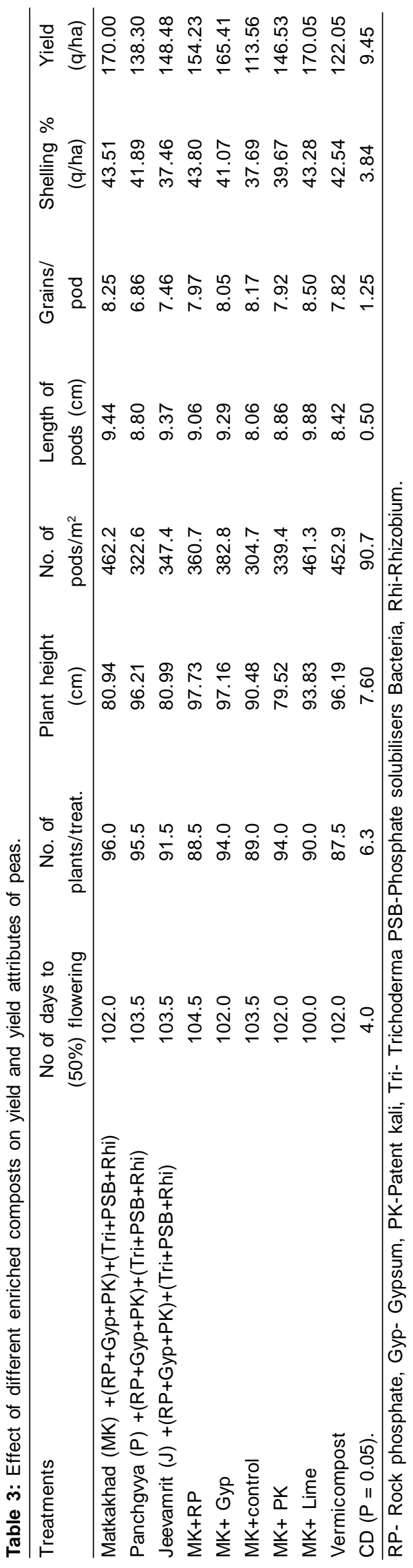


Table 4: Effect of different enriched composts on yield and yield attributes of Capsicum.

\begin{tabular}{|c|c|c|c|}
\hline Treatments & Plant height $(\mathrm{cm})$ & No. of fruits $/ \mathrm{m}^{2}$ & Yield (q/ha) \\
\hline Matka khad $(\mathrm{MK})+(\mathrm{RP}+\mathrm{Gyp}+\mathrm{PK})+($ Tri+PSB+Azo. $)$ & 136.2 & 13.6 & 143.8 \\
\hline Panchgavya $(P)+(R P+G y p+P K)+($ Tri $+P S B+A z o)$. & 127.6 & 12.4 & 140.0 \\
\hline Jeevamrit $(J)+(R P+G y p+P K)+($ Tri+PSB+Azo.) & 135.0 & 13.4 & 145.7 \\
\hline $\mathrm{MK}+\mathrm{RP}$ & 111.5 & 12.0 & 138.0 \\
\hline MK+Gyp & 204.4 & 15.4 & 149.5 \\
\hline MK+control & 165.1 & 10.0 & 120.2 \\
\hline $\mathrm{MK}+\mathrm{PK}$ & 192.2 & 13.8 & 138.1 \\
\hline MK+Lime & 184.2 & 12.8 & 125.7 \\
\hline Vermicompost & 116.3 & 11.4 & 126.2 \\
\hline$C D(p=0.05)$ & 12.2 & 1.0 & 8.1 \\
\hline
\end{tabular}

RP- Rock phosphate, Gyp- Gypsum, PK- Patent kali, Tri- Trichoderma PSB- Phosphate solubilisers bacteria, Azo-Azotobacter.

Table 5: Microbial status of different organic manures.

\begin{tabular}{|c|c|c|c|c|c|}
\hline \multirow{2}{*}{ Treatments } & \multicolumn{5}{|c|}{ Microbial count (log CFU) } \\
\hline & Bacteria & Fungi & Actinomycetes & Azotobacter & PSB \\
\hline Matka khad $(\mathrm{MK})+(\mathrm{RP}+\mathrm{Gyp}+\mathrm{PK})+(\mathrm{Tri}+\mathrm{PSB}+\mathrm{Rhi})$ & 9.61 & 3.60 & 4.43 & 4 & 2.28 \\
\hline Panchgavya $(P)+(R P+G y p+P K)+($ Tri $+P S B+R h i)$ & 8.47 & 3.25 & 5.62 & 4.99 & 2.41 \\
\hline Jeevamrit $(J)+(R P+G y p+P K)+($ Tri+PSB+Rhi) & 8.51 & 2.30 & 4.56 & 4.82 & ND \\
\hline $\mathrm{MK}+\mathrm{RP}$ & 9.10 & 3.48 & 5.02 & 4.74 & 2.03 \\
\hline MK+Gyp & 9.37 & 3.69 & 5.24 & 4.94 & ND \\
\hline MK+control & 9.34 & 2.60 & 5.91 & 4.93 & ND \\
\hline $\mathrm{MK}+\mathrm{PK}$ & 9.54 & 3.30 & ND & 4.69 & 2.17 \\
\hline MK+Lime & 9.34 & 3.74 & 5.03 & 4.82 & ND \\
\hline Vermicompost & 7.74 & 5.54 & 7.15 & 6.26 & 5.57 \\
\hline
\end{tabular}

RP- Rock phosphate, Gyp- Gypsum, PK- Patent kali, Tri- Trichoderma PSB- Phosphate solubilisers bacteria, Rhi- Rhizobium.

treatment followed MK + (RP+Gyp+PK) + (Tri. + PSB + Azo.). Maximum capsicum yield was obtained with the treatment $\mathrm{MK}+$ Gypsum which was $18.5 \%$ higher than the application of vermicompost treatment. Although $\mathrm{MK}+(\mathrm{RP}+\mathrm{Gyp}+\mathrm{PK})$ $+($ Tri. + PSB + Azo. $), P+(R P+G y p+P K)+($ Tri. + PSB + Azo.) and $\mathrm{J}+(\mathrm{RP}+\mathrm{Gyp}+\mathrm{PK})+($ Tri. $+\mathrm{PSB}+\mathrm{Azo}$.) treatments were significantly at par with the treatment $M K+$ Gypsum (Table 4).

\section{Microbial status of different organic manures}

Among various treatments bacteria count ranged from 7.749.61, maximum values of bacteria were recorded in Matka khad + $(R P+G y p+P K)+($ Tri. + PSB + Rhi. $)$ treatment and minimum in vermicompost. Fungi values varied from 2.305.54 , maximum in vermicompost and minimum values were recorded in Jeevamrit + $(\mathrm{RP}+\mathrm{Gyp}+\mathrm{PK})+($ Tri. $+\mathrm{PSB}+\mathrm{Rhi}$. treatments. Values of Actinomycetes were maximum in vermicompost 7.15 and minimum in $\mathrm{MK}+(\mathrm{RP}+\mathrm{Gyp}+\mathrm{PK})+$ (Tri. + PSB + Rhi.) 4.43. Similiar results were recorded for Azotobacter. For most of the treatments PSB were not detected and maximum values was recorded in vermicompost treatment (Table 5).

\section{Nutrient status of different organic manures}

The $\mathrm{pH}$ of the treatments ranged from 5.6-7.4 and the highest value in $\mathrm{MK}+(\mathrm{RP}+\mathrm{Gyp}+\mathrm{PK})+($ Tri. $+\mathrm{PSB}+\mathrm{Rhi}$. $)$ and lower value in vermicompost was recorded (Fig 1). Nitrogen content ranged from 1.05-1.97 and found maximum content in $\mathrm{MK}+$ Lime followed by $\mathrm{MK}+\mathrm{RP}$ and $\mathrm{MK}+$ gypsum. Phosphorus percentage found maximum in $\mathrm{MK}+$ $(R P+G y p+P K)+($ Tri. + PSB + Rhi. $)$ and minimum in MK + lime, whereas, Potassium varies from 0.34-1.04 with maximum value $\mathrm{MK}+(\mathrm{RP}+\mathrm{Gyp}+\mathrm{PK})+($ Tri. $+\mathrm{PSB}+\mathrm{Rhi}$. followed by $P+(R P+G y p+P K)+($ Tri. $+P S B+$ Rhi. $)$. Other elements like $\mathrm{Ca}, \mathrm{Mg}$ and $\mathrm{S}$ also shows similar results with higher values in $\mathrm{MK}+(\mathrm{RP}+\mathrm{Gyp}+\mathrm{PK})+($ Tri. $+\mathrm{PSB}+\mathrm{Rhi}$. followed by $\mathrm{MK}+$ Lime.

\section{Trial conducted at farmer's fields}

\section{In Akrot (Una)}

Capsicum and pea crops were tested under polyhouse conditions. The different enriched composts significantly increased yield of both crops as compared to vermicompost except MK + Gypsum, MK + control, MK + PK, MK + Lime treatments where the yield in case of capsicum was significantly at par with each other. In capsicum and Pea crops maximum yield was recorded in $\mathrm{MK}+(\mathrm{RP}+\mathrm{Gyp}+\mathrm{PK})$ + (Tri. + PSB +Azb.) which was $45 \%$ and $61 \%$ higher than application of vermicompost (Table 6).

\section{In Rajol (Kangra)}

The different enriched composts significantly increased the capsicum and pea yield as compared to application of vermicompost. In case of pea crop $\mathrm{MK}+$ Lime tratment 


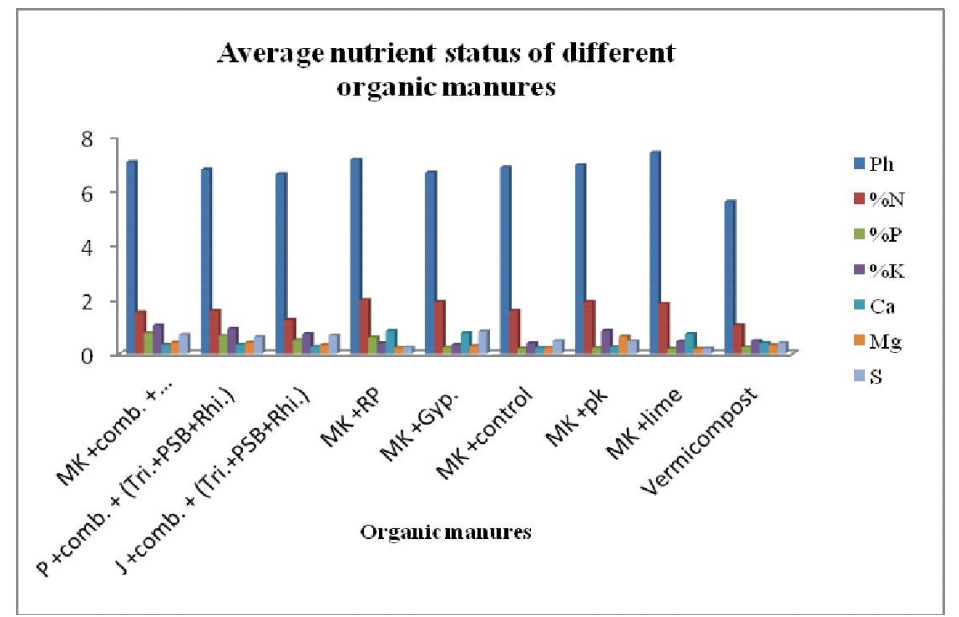

Fig 1: Average nutrient status of different organic manures.

*MK- Matka khad, P- Panchgavya, J- Jeevamrit, Comb. - (RP+Gyp+PK), RP- Rock phosphate, Gyp- Gypsum, PK- Patent kali, Tri- Trichoderma, PSB- Phosphate solubilisers bacteria, Rhi- Rhizobium.

Table 6: Effect of different enriched composts on yield of capsicum and peas crops under farmers' fields under polyhouse conditions.

\begin{tabular}{lcccc}
\hline \multirow{2}{*}{ Treatments } & \multicolumn{2}{c}{ Akrot Una } & \multicolumn{2}{c}{ Rajol Kangra } \\
\cline { 2 - 5 } & $\begin{array}{c}\text { Capsicum yield } \\
(\mathrm{q} / \mathrm{ha})\end{array}$ & $\begin{array}{c}\text { Pea yield } \\
(\mathrm{q} / \mathrm{ha})\end{array}$ & $\begin{array}{c}\text { Capsicum yield } \\
(\mathrm{q} / \mathrm{ha})\end{array}$ & $\begin{array}{c}\text { Pea yield } \\
(\mathrm{q} / \mathrm{ha})\end{array}$ \\
\hline Matka khad (MK) + (RP+Gyp+PK) + (Tri+PSB+Rhi/Azo) & 140.23 & 178.20 & 135.32 & 130.25 \\
Panchgavya (P) + (RP+Gyp+PK) + (Tri+PSB+Rhi/Azo) & 108.58 & 120.54 & 110.12 & 122.59 \\
Jeevamrit (J) + (RP+Gyp+PK) + (Tri+PSB+Rhi/Azo) & 135.25 & 168.35 & 125.85 & 122.54 \\
MK+RP & 115.08 & 167.42 & 110.25 & 128.25 \\
MK+Gyp & 100.25 & 145.30 & 100.58 & 125.45 \\
MK+control & 98.50 & 125.45 & 106.18 & 100.25 \\
MK+PK & 95.52 & 140.25 & 116.35 & 100.24 \\
MK+Lime & 91.25 & 135.20 & 100.74 & 92.45 \\
Vermicompost & 97.04 & 110.36 & 91.65 & 90.47 \\
CD ( = 0.05) & 6.52 & 8.25 & 8.20 & 7.10 \\
\hline RP-Rok phosphyyyyyyyyy
\end{tabular}

RP- Rock phosphate, Gyp- Gypsum, PK- Patent kali, Tri- Trichoderma, PSB- Phosphate solubilisers bacteria, Rhi- Rhizobium, AzoAzotobacter.

produced yield significantly at par with vermicompost. In capsicum and pea maximum yield was recorded in $\mathrm{MK}+$ $(\mathrm{RP}+\mathrm{Gyp}+\mathrm{PK})+($ Tri. $+\mathrm{PSB}+\mathrm{Rhi} / \mathrm{Azb}$. $)$ which was $48 \%$ and $44 \%$ higher than application of vermicompost respectively. In capsicum application of $J+(R P+G y p+P K)$ $+($ Tri. + PSB +Azb.) was the second best treatment which produced $37 \%$ higher production as compared to application of vermicompost, whereas in case of peas MK + RP treatments was significantly at par with $\mathrm{J}+(\mathrm{RP}+\mathrm{Gyp}+\mathrm{PK})+$ (Tri. + PSB +Rhi.) (Table 6).

\section{CONCLUSION}

It was found that the inoculation of biomass with matka khad and use of additives i.e. rock phosphate, gypsum, patent kali and lime @ of 1\% and fortification with Tricoderma, suitable biofertilizer (Rhizobium/Azotobacter) along with PSB improved the microbial count, increased yield of pea crop
(40 to $61 \%$ ) and capsicum crop (14 to $48 \%$ ) both at organic farm and farmers' fields as compared to application of vermicompost alone.

\section{REFERENCES}

Caravaca, F.J., Barea, M. and Roldan, A. (2002). Synergistic influence of an arbuscular mycorhizal fungus and organic amendment on Pistacia lentiscus L. seedlings aforested in a degraded semi-arid soil. Soil Biology and Biochemistry. 34: 139-145.

Eghball, B., Ginting, D. and Gilly, J.E. (2004). Residual effects of manures and compost application on corn production and soil properties. Agronomy Journal. 96: 442-447.

Muthukumar, T. and Udaiyan, K. (2000). Influence of organic manures on arbuscular mycorhizal fungi asociated with [Vigna unguiculata (L.) Walp]. in relation to tissue nutrients and soluble carbohydrate in rots under field conditons. Biology and Fertilty of Soils. 31: 114-120. 
Nyamangara, J., Bergstrom, L.F., Piha, M.I and Giler, K.E. (2003). Fertilzer use efficiency and nitrate leaching in a tropical sandy soil. Journal of Environment Quality. 32: 59-606.

Nziguheba, G., Merckx, R., Palm C.A. and Rao. M.R. (2000). Organic residues affect phosphorus availabilty and maize yields in a Nitsol of Western Kenya. Biology and Fertilty of Soils. 32: 328-33.

Palaniappan, S. P. and Annadurai, K. (1999). Organic Farming Theory and Practice. Scientific Publisher; Jodhpur.

Pazhanivelan, S., Amanullah, M.M., Vaiyapuri, K., Rahale, C.S., Sathyamoorthi, K. and Alagesan, A. (2006). Effect of rock phosphate incubated with FYM on nutrient uptake and yield of lowland rice. Research Journal of Agriculture Biology Science. 2(6): 365-368.
Singh, S., Mishra, M.M., Goyal, S. and Kapoor, K.K. (1992). Preparation of nitrogen and phosphorous enriched compost and its effect on wheat (Triticum aestivum). Indian Journal of Agricultural Sciences. 62: 810-814.

Shrestha Vaidya, G., Shrestha, K., Khadge, B.R., Johnson, N.C. and Walander, H. (2008). Organic matter stimulates arbuscular mycorhizal fungi in Bauhinia purpurea and Leucaenia diversifolia plantations on eroded slopes in Nepal. Restoration Ecology. 16(1): 79-87. 